\title{
The Impact of User-Generated Content on Customer Loyalty in Food and Beverages Retail: An Empirical Study
}

\author{
Roger Seiler \\ Zurich University of Applied Science \\ Bettina Beurer-Zuellig \\ Zurich University of Applied Science \\ Anna Rozumowski \\ Zurich University of Applied Science
}

\begin{abstract}
This study analyses the effect of user-generated content (UGC) on the loyalty of UGC recipients in a European retail environment. An online experiment was conducted, which returned 1,074 completed questionnaires. Intensive involvement with UGC significantly increases the affective loyalty of retail customers, but no significant effect was found on conative loyalty. Furthermore, trust in UGC results in significantly higher conative and affective loyalty levels. Specifically, we reveal differences in the loyalty dimensions of millennials, with UGC significantly impacting affective loyalty in this age group. Our results suggest that UGC contributes to customer loyalty and patronage in a retail setting.
\end{abstract}

Keywords: user-generated content, customer loyalty, food retail, experiment

\section{INTRODUCTION}

The food and beverages retail market, as well as the personal care retail market, is highly competitive. According to (Statista 2018), price and assortment strategies do not suffice to differentiate, whereas customer engagement may hold the key to strong customer relationships and loyalty. Customer integration reinforces customer business relationships (Arnhold 2010). Consumers are moving to the centre of retailers' attention, as communication patterns are shifting from traditional one-way to two-way communication (Allan J. Kimmel 2010; Berthon, Pitt, and Campbell 2008). Consumers comment on their experience with retailers, exchange advice (Cheung, Lee, and Rabjohn 2008; Chu and Kim 2011; Erkan and Evans 2016; Kim and Johnson 2016) and inspire other consumers (Halliday 2016). User-generated content (UGC) is "created by the general public" (Arnhold 2010, p. 33), thereby not necessarily focusing on financial interests (Ralph Stöckl, Patrick Rohrmeier, and Thomas Hess 2008). Brand-related UGC refers to "the voluntary creation and public distribution of a personal brand meaning" (Arnhold 2010, p. 33). By creating brandrelated content, consumers shape the general perception of a brand (Daniel Rowles 2014; Khim-Yong Goh, Cheng-Suang Heng, and Zhijie Lin 2013). UGC is perceived to be objective, impartial (Mir and Ur Rehman 
2013) and more credible than producer-generated content (PGC) (Cheong and Morrison 2008; MacKinnon 2012; Mir and Ur Rehman 2013).

Consumers rely on UGC for purchasing decisions (MacKinnon 2012; Ramanathan et al. 2017). UGC consumption has a positive impact on brand awareness, brand loyalty and perceived quality (Schivinski and Dabrowski 2015). Content creation positively influences purchase intention (Malthouse et al. 2016). Social media has become mainstream in the marketing mix, with $12 \%$ of the marketing budget spent on social media (The CMO Survey 2018). Recent figures suggest that $63 \%$ of companies are utilizing social media to leverage customer loyalty (Social Media Examiner 2018). To combat competitive pressure, companies are striving for long-term customer relationships (Jaritz 2008). Conversion of customers into patrons and binding them closer to the brand is a major goal for retailers to ensure sustainable revenues (Hogreve et al. 2017). User-generated branding utilizes brand-related UGC to achieve brand goals (Burmann 2010). Our study examines the influence of UGC on customer loyalty, using involvement and trust as independent variables.

\section{THEORETICAL CONTEXT}

Trust is the cornerstone of business relations and success, as trust can have positive effects on purchasing intentions (Hegner 2011; McKnight, Choudhury, and Kacmar 2002). Customer loyalty, a marketing goal, is important too because it can help to achieve a company's economic goals (Diller 1996). Furthermore, trust can have positive effects on customer loyalty (Kim and Peterson 2017), which in turn positively affects a company's success (see e.g. Smith and Wright (2004)). Trust can be built through content creation by companies (Cheong and Morrison 2008) as well as customers (Utz, Kerkhof, and Bos 2012). The former is generally referred to as firm-generated content (FGC) or producer-generated content (PGC), and the latter as user-generated content (UGC) or consumer-generated content (CGC). For simplicity, we will use the terminology of UGC and FGC because we do not want to differentiate or subdivide the concepts any further.

Trust is important online and can have a positive effect on a customer's purchasing intentions (Hegner 2012; Kim and Peterson 2017; McKnight, Choudhury, and Kacmar 2002). Furthermore, trust can be subdivided into cognitive and emotional trust. Cognitive trust is a rational expectation of the competence of the other party (Choi and Lee 2017; Hegner 2012; Komiak and Benbasat 2004; Soh, Reid, and WhitehillKing 2009), it relates to consumers' experiences and acquired knowledge with a brand (Hegner 2012; Vollmar, Becker, and Hoffend 2013). Emotional trust is an affective expectation that the opposite party acts in one's interests (Choi and Lee 2017; Hegner 2012; Komiak and Benbasat 2004) characterizing a person's emotions toward an object or a person (Vollmar et al., 2013). Affective trust plays an important role in routine activities and everyday decision-making, which is the case for the majority of grocery purchases (Hegner 2012). Regarding content online, UGC is perceived as more trustworthy than PGC (Cheong and Morrison 2008; MacKinnon 2012; Mir and Ur Rehman 2013). Choi \& Lee (2017) show that UGC has a larger effect on cognitive trust than PGC, while PGC has a larger effect on affective trust than UGC.

Customer loyalty has positive effects on a company's performance (Ramanathan et al. 2017; Smith and Wright 2004). Furthermore, the concept of customer loyalty can be subdivided into an affective, cognitive, conative and action dimension (Oliver 2014). This view of customer loyalty is shared by researchers modelling the concept online and providing an e-loyalty framework (Gommans, Krishman, and Scheffold 2001). In models of e-loyalty, content and trust are modelled as drivers of customer loyalty. These models have been shown to be valid in brick and mortar environments as well (Dick and Basu 1994; Vinhas Da Silva and Faridah Syed Alwi 2006). Too, Souchon, \& Thirkell (2001), too, point out that a multi-faceted operationalisation in a retail context is a "fruitful basis for empirical enquiry". Furthermore, these authors point out that the strongest customer loyalty conceptualisations are multi-faceted constructs, referring to statements by Fournier \& Yao (1997) that taking into account psychological as well as behavioural components give multi-faced operationalisations their strength. Content or more specifically UGC generates cognitive as well as emotional responses (Kim and Johnson 2016). A multi-level model shows that a brand community has positive effects on trust, which in turn positively affects brand loyalty (Laroche 
et al. 2012). These effects on trust and loyalty are confirmed in a model that focusses on customer relationships (Laroche, Habibi, and Richard 2013). However, previous research does not yet distinguish or subdivide customer loyalty in the context of UGC, even though emotional responses are to be expected. In addition (Hollebeek and Macky 2019) recommend a further study of digital content marketing (DCM) consequences such as trust and loyalty for different firm characteristics.

Research on word-of-mouth marketing (WOM) and e-WOM suggests that customers rely not only on WOM and e-WOM but also on UGC when making purchasing decisions (Lee and Shin 2014), (Ramanathan, Subramanian, and Parrott 2017). Moreover, WOM can be an antecedent of customer loyalty (Srinivasan, Anderson, and Ponnavolu 2002) as well as an outcome of brand loyalty (Bıçakcıŏlu, İpek, and Bayraktaroğlu 2018).

Furthermore, involvement plays an important role when one examines in detail how customers process information, i.e. UGC and FGC. Costley \& Brucks (1987) find evidence in their meta-analysis that involvement influences the depth of information processing, the purchasing decision, and loyalty and WOM. In addition, a closed loop between UGC, involvement and brand value exists (Christodoulides, Jevons, and Bonhomme 2012). Although grocery products are typically categorized as low-involvement products, significant differences in involvement within the categories were identified by Knox, Walker, \& Marshall (2015). Furthermore, a link between involvement and customer loyalty was identified (Knox and Walker 2003). Kim and Johnson (2016), too, provide evidence that UGC triggers an emotional and cognitive reaction that ultimately impacts behaviour. Involvement is therefore a relevant construct when it comes to explaining consumer behaviour.

Current literature links UGC to trust, but involvement and positive effects on customer loyalty have been reported too. However, to our knowledge, no evidence or studies exist that explore customer loyalty in the context of UGC in an offline retailing setting in which loyalty is subdivided. We therefore close this gap by subdividing customer loyalty into an affective, emotional, and behavioural conative component. Additionally, we use a conceptualization of trust that has both emotional and cognitive aspects.

\section{HYPOTHESES}

A significant relationship between involvement and customer loyalty exists in grocery retailing (Knox and Walker 2003). This evidence is further supported by meta-analyses (Costley and Brucks 1987) and by the closed loop between UGC, involvement and brand value identified by Christodoulides, Jevons, and Bonhomme (2012). Our first hypothesis, H1, therefore states that highly involved customers show higher levels of customer loyalty:

H1a: Due to the intensive involvement with user-generated media content, affective loyalty increases among highly involved persons.

H1b: Due to the intensive involvement with user-generated media content, conative loyalty increases among highly involved persons.

Hypotheses $\mathrm{H} 1 \mathrm{a}$ and $\mathrm{H} 1 \mathrm{~b}$ relate to the emotional involvement with user-generated media content and its effect on the two forms of customer loyalty. UGC has previously been shown to affect trust (Choi and Lee 2017), and trust is based on customers' positive past experiences with a brand, building trust accounts and resulting in customer loyalty (Ball, Simões Coelho, and Machás 2004; Delgado-Ballester and Luis Munuera-Alemán 2005). We therefore derive our second hypothesis, H2, stating that people who show high levels of trust in UGC show higher levels of customer loyalty:

H2a: Trust in user-generated media content increases customers' affective loyalty.

H2b: Trust in user-generated media content increases customers' conative loyalty. 
With reference to Diller's model for customer loyalty (Diller 1996), the effect of user-generated media content on customer loyalty is measured by conducting a survey. The determinants involvement and trust are chosen as independent variables. They are measured in relation to three examples of user-generated media content. The study outcome is customer loyalty, which is treated as the dependent variable. A detailed analysis of customer loyalty is conducted with regard to age, gender, educational level, and shopping habits.

\section{METHODOLOGY}

To measure involvement, the Personal Involvement Inventory for Advertising (PIIA) was used from Zaichkowsky (1994). To measure trust, two different constructs from Choi and Lee (2017) were included in the survey: cognitive and emotional trust. Moreover, conative customer loyalty was measured to determine repurchase, recommendation and cross-buying intentions. The scales have been adapted to the retail sector. The pre-test showed that some questions were vaguely formulated; therefore, these questions were improved for the questionnaire. The subpopulation of test subjects was selected in such a way that the results could be scaled as accurately and reliably as possible to the entire population. Participants were recruited via a dark post on Facebook. The experiment was designed as follows. Firstly, the definition of user-generated content was given to the participants. Secondly, to rule out medium bias one of the three manipulations were randomly shown to the participants, either a Facebook post displaying pictures with retailers' groceries and a BBQ scene, an Instagram post showing retailers' product with serving suggestion or a Google review of the retailer. Thirdly, the survey to measure the dependent and independent variables was conducted.

\section{EMPIRICAL FINDINGS}

In total, 155,904 persons saw the ad, and 18'723 people clicked on the link. Altogether, 1,074 completed surveys were examined for anomalies, which left us with a sample size of $n=986$. In total, 777 women and 209 men participated in the study. The customer base of the European retailer shows a high share of women as well. Education level was high in the sample, with $45,8 \%$ university graduates and $28.1 \%$ high school graduates. Most (27,2\%) participants were aged between 25 and 34 years, 24,3\% were 45-59 years, and $22.2 \%$ were $18-24$ years old

Analysing the participants' shopping habits, we found that $42,5 \%$ visit the retailer several times a month, and $25,7 \%$ several times a week. The following reliabilities values were obtained: involvement $(\alpha=.892)$, trust $(\alpha=.917)$, affective customer loyalty $(\alpha=.936)$, and conative customer loyalty $(\alpha=.879)$. Thus, no items were deleted as all values exceed .7, as proposed by Nunally (1978). In this paper, the significance level $\alpha$ is $5 \%$; effects with p-values smaller than 0.05 are considered significant.

The ordinal-scaled variables are measured using Spearman's correlation. The frequency of purchasing and the share-of-wallet correlate strongly and highly significantly $(r s=.602, p \leq .001, n=986)$. A weak but highly significant correlation was found between frequency of purchasing and educational level ( $\mathrm{rs}=$ $.156, \mathrm{p} \leq .001, \mathrm{n}=986)$ and between share-of-wallet and age of subjects $(\mathrm{rs}=.112, \mathrm{p} \leq .001, \mathrm{n}=986)$.

A principal component analysis was conducted with Varimax rotation to reduce the number of dimensions and to identify the underlying factors influencing affective and conative loyalty. The measure of sample suitability according to Kaiser-Meyer-Olkin $(\mathrm{KMO}=.921)$ corresponds to an "astonishing" value (Hutcheson and Sofroniou 1999). The Bartlett test confirms that the variables are not completely uncorrelated $\left(\chi^{2}(210)=15134.054, p \leq .001\right)$. An analysis of factors is therefore permissible. Cross-loading items were deleted from the analysis using the Kaiser criterion (eigenvalue $>1$ ), which left us with four factors. Factor 1 corresponds to cognitive and emotional trust, which is expressed as trust. Factor 2 shows conative loyalty, and factor 3 affective loyalty. The fourth factor defines involvement. Together, the four factors explain $68.81 \%$ of the total variance.

Pearson's correlations are derived for the interval-scaled variables. Involvement and trust correlate highly significantly $(\mathrm{r}=.569, \mathrm{p} \leq .001, \mathrm{n}=986)$. The higher the involvement in user-generated media content, the higher the trust in it, and vice versa. Involvement correlates positively and highly significant 
with conative loyalty $(\mathrm{r}=.233, \mathrm{p} \leq .001, \mathrm{n}=986)$ and affective loyalty $(\mathrm{r}=.334, \mathrm{p} \leq .001, \mathrm{n}=986)$. Trust correlates positively and highly significant with conative loyalty $(r=.338, p \leq .001, n=986)$ and affective loyalty $(\mathrm{r}=.427, \mathrm{p} \leq .001, \mathrm{n}=986)$. Thus, the higher the trust in user-generated content, the higher the affective and conative loyalty. However, the affective loyalty had a stronger impact than the conative loyalty. To analyse further the results and to accept or reject the postulated hypotheses, a multiple regression analysis was conducted.

Taking affective loyalty or conative loyalty as dependent variable, the variance inflation factor (VIF) is 1.478 and the tolerance value is 677 (Urban, Dieter and Jochen Mayerl 2011). The conative loyalty as dependent variable explains $11.7 \%$ of the model $(\mathrm{R}$-squared $=.117)$. The F-value indicates the suitability of the model with conative loyalty as dependent variable $(\mathrm{F}(2,983)=65.056, \mathrm{p} \leq .001)$. Analysing the strength of the impact on the dependent variable, we found that involvement $(b=.049, \mathrm{p}=.101, \mathrm{SE}=.030)$ shows a non-significant impact on conative loyalty, whereas trust shows both a strong and highly significant impact $(b=.262, \mathrm{p} \leq .001, \mathrm{SE}=.031)$.

The affective loyalty as dependent variable explains $19.5 \%$ of the model $(\mathrm{R}$-squared $=.195)$. The Fvalue indicates the suitability of the model $(\mathrm{F}(2,983)=119.007, \mathrm{p} \leq .001)$. Both involvement $(b=.161, \mathrm{p}$ $\leq .001, \mathrm{SE}=.042)$ and trust $(b=.438, \mathrm{p} \leq .001 . \mathrm{SE}=.043)$ show a highly significant impact on affective customer loyalty. Trust shows the greatest impact.

A significant impact was found for $\mathrm{H} 1 \mathrm{a}$ but not for $\mathrm{H} 1 \mathrm{~b}$. Both hypotheses on trust, $\mathrm{H} 2 \mathrm{a}$ and $\mathrm{H} 2 \mathrm{~b}$, are supported. Because customer loyalty is a core construct in our study, we further analysed the control variables (age, gender, education level and purchasing behaviour). The purchasing frequency shows highly significant group differences in conative customer loyalty $(\mathrm{F}(4,981)=112.563, \mathrm{p} \leq .001$, partial $\eta 2=.315)$. Test persons with a shopping frequency of "several times a week" display the highest customer loyalty (M $=6.1597, \mathrm{SD}=.77569)$. Regarding affective customer loyalty, highly significant group differences were observed in purchasing frequency $(\mathrm{F}(4,981)=95.542, \mathrm{p} \leq .001$, partial $\eta 2=.280)$. Customers who shop daily at the retailer have the highest affective customer loyalty $(\mathrm{M}=5.3232, \mathrm{SD}=1.55788)$. The different levels of share-of-wallet show highly significant differences in conative customer loyalty $(\mathrm{F}(9,976)=$ $57.950, \mathrm{p} \leq .001$, partial $\eta 2=.348)$ and affective customer loyalty $(\mathrm{F}(9,976)=49.452, \mathrm{p} \leq .001$, partial $\eta 2$ $=.313)$. There are no significant group differences in gender, neither for conative customer loyalty $(\mathrm{F}$ $(1,984)=.017, p>.05$, partial $\eta 2=.000)$ nor for affective customer loyalty $(F(1,984)=.833 p>.05$, partial $\eta 2=.001)$. Age does not cause any significant group differences in conative customer loyalty $(\mathrm{F}(4,981)$ $=1.192, \mathrm{p}>.05$, partial $\eta 2=.005)$. Affective customer loyalty differs according to age with a weak significance $(\mathrm{F}(4,981)=3.468, \mathrm{p} \leq .05$, partial $\eta 2=.014)$. Test persons over 60 years old showed the highest affective customer loyalty $(\mathrm{M}=3.4719, \mathrm{SD}=1.62739$. The youngest age group (18 - 24 years) has the lowest customer loyalty $(\mathrm{M}=3.1309, \mathrm{SD}=1.55337)$. Analysing the age group differences in terms of affective customer loyalty, we found only small, non-significant differences. The educational level of the test persons also shows highly significant group differences in conative customer loyalty $(\mathrm{F}(5,980)=6.681$, $\mathrm{p} \leq .001$, partial $\eta 2=.033$ ). Test subjects with vocational education showed the highest customer loyalty $(\mathrm{M}=5.8800, \mathrm{SD}=.89996)$. There are also highly significant group differences in educational level and affective customer loyalty $(F(5,980)=12.404, p \leq .001$, partial $\eta 2=.060)$. Persons with a certificate of secondary education showed the largest customer loyalty $(\mathrm{M}=4.5444, \mathrm{SD}=1.44499)$. Participants with a $\mathrm{PhD}$ or habilitation showed the lowest affective customer loyalty $(\mathrm{M}=2.8939, \mathrm{SD}=1.70088)$.

\section{DISCUSSION AND CONCLUSION}

\section{Theoretical Implications}

Whereas previous research focusses on motivations to generate content (Berthon, Pitt, and Campbell 2008; Daugherty, Eastin, and Bright 2008; Malthouse et al. 2016), our research contributes to a greater understanding of the influence of UGC on recipients reactions, i.e. customer loyalty and its affective and conative dimension. Our results are in line with A. J. Kim \& Johnson (2016), who state that UGC triggers emotional and cognitive reactions. Furthermore we contribute to the understanding of the value of UGC for offline business, namely food retailing, showing that UGC has an impact on attitude formation as well as 
purchasing intentions, in line with previous research of MacKinnon (2012) and Ramanathan, Subramanian and Parrott (2017).

\section{Practical Implications}

The regression analysis partially confirms a significant effect of involvement and trust on the two forms of customer loyalty. Based on these findings, a recommendation can be given on how to deal with usergenerated media content. For practical implementation, it is also of interest to identify group differences within a population of people.

The data of this study indicate that it is valid to embed UGC in marketing activities because of the positive effects on customer loyalty, an antecedent of retention (Curtis et al. 2011), which in turn has a positive effect on a company's performance (Ramanathan, Subramanian, and Parrott 2017; Smith and Wright 2004). This implication is in line with findings of Blut, Teller, and Floh (2018) linking marketing mix and communication to patronage. Our findings highlight the importance of UGC for patronage in offline grocery shopping as our results confirm that trust highly impacts affective loyalty, which plays a dominant role in routine activities and everyday decision-making (Hegner 2012). Furthermore, UGC positively affects customer satisfaction (Colicev, Kumar, and O'Connor 2018), an antecedent of customer loyalty (Kuenzel and Halliday 2010). However, a note of warning is appropriate, as contemporary marketing increasingly resembles UGC. If customers confuse FGC and UGC, an uncanny valley effect (see Ciechanowski et al. (2019) for a chatbot experiment) - i.e. customers believe they are reading reviews of a fellow shopper and then suddenly realise they are looking at advertisements - opposite effects to the desired ones may occur. Furthermore, the effects may vary across channels (Roma and Aloini 2019), an aspect that should be taken into account too

According to our data, younger customers are less loyal. This is in line with studies on millennials showing lower customer loyalty to commodity goods (Gurău 2012; Lodes, Megan and Buff, Cheryl L. 2009), but with UGC positively affecting their loyalty, especially affective loyalty and not conative loyalty. Furthermore, a positive correlation between share-of-wallet and age was reported. Both these aspects support our argument that UGC should be considered in marketing activities and strategy.

\section{Limitations and Further Research}

Customer loyalty is measured as intention and not as actual customer behaviour. Research following up on our research could compare the stated purchase intentions to actual purchasing behaviour by linking these intentions to actual data of loyalty programs and customer profiles. Obviously, brand and region bias is involved in this study.

Furthermore, a promising research question would be to analyse which UGC type (pictures, videos and text) via which channel (Facebook, Instagram and others) have the greatest impact on customer loyalty. Our research contributes to discerning the influence of UGC on marketing performance, with customer loyalty as measure. The preliminary results could be extended, as suggested by Roma and Aloini (2019). They recommended that further research on how brand related UGC can be employed in social media marketing strategies, and their impact on marketing performance measures, should be conducted.

\section{Conclusion}

Our results suggest that UGC is relevant and useful to marketeers seeking to increase marketing performance and company success because UGC has an impact on both attitude formation and purchase intentions. UGC has the potential to bridge the gap between online and offline shopping experience, triggering affective as well as conative responses. Furthermore, trust impacts affective and conative customer loyalty. In addition, the effects we observed are in line with previous research linking the use of UGC in marketing to patronage (Blut, Teller, and Floh 2018), as well as research linking UGC to customer satisfaction (Colicev, Kumar, and O'Connor 2018), an antecedent of customer loyalty. Involvement affects affective customer loyalty, but we found no significant effect on conative loyalty. Our research suggests that UGC is effective for the target segment of millennials, confirming findings of (Bowen and Chen 
McCain 2015) (Bowen and Chen McCain 2015) identifying the perception of friends and peers in social networks as an antecedent of trust.

\section{REFERENCES}

Arnhold, U. (2010). User Generated Branding. Wiesbaden: Gabler.

Ball, D., Coelho, P.S., \& Machás, A. (2004). The role of communication and trust in explaining customer loyalty: An extension to the ECSI model. European Journal of Marketing, 38(9/10), 1272-93.

Berthon, P., Pitt, L., \& Campbell, C. (2008). Ad lib: When customers create the ad. California Management Review, 50(4), 6-30.

Biçakcioğlu, N., İpek, I., \& Bayraktaroğlu, G. (2018). Antecedents and outcomes of brand love: the mediating role of brand loyalty. Journal of Marketing Communications, 24(8), 863-77.

Blut, M., Teller, C., \& Floh, A. (2018). Testing Retail Marketing-Mix Effects on Patronage: A MetaAnalysis. Journal of Retailing, 94(2), 113-35.

Bowen, J.T., \& McCain, S-L.C. (2015). Transitioning loyalty programs: A commentary on 'the relationship between customer loyalty and customer satisfaction.' International Journal of Contemporary Hospitality Management, 27(3), 415-30.

Burmann, C. (2010). A call for 'User-Generated Branding.' Journal of Brand Management, 18(1), 1-4.

Cheong, H.J., \& Morrison, M.A. (2008). Consumers' Reliance on Product Information and Recommendations Found in UGC. Journal of Interactive Advertising, 8(2), 38-49.

Cheung, C.M.K., Lee, M.K.O., \& Rabjohn, N. (2008). The impact of electronic word-of-mouth: The adoption of online opinions in online customer communities. Internet Research, 18(3), 229-47.

Choi, B., \& Lee, I. (2017). Trust in open versus closed social media: The relative influence of user- and marketer-generated content in social network services on customer trust. Telematics and Informatics, 34(5), 550-59.

Christodoulides, G., Jevons, C., \& Bonhomme, J. (2012). Memo to Marketers: Quantitative Evidence for Change: How User-Generated Content Really Affects Brands. Journal of Advertising Research, 52(1), 53-64.

Chu, S-C., \& Kim, Y. (2011). Determinants of consumer engagement in electronic word-of-mouth (eWOM) in social networking sites. International Journal of Advertising, 30(1), 47-75.

Ciechanowski, L., Przegalinska, A., Magnuski, M., \& Gloor, P. (2019). In the shades of the uncanny valley: An experimental study of human-chatbot interaction. Future Generation Computer Systems, 92, 539-48.

Colicev, A., Kumar, A., \& O'Connor, P. (2018). Modeling the relationship between firm and user generated content and the stages of the marketing funnel. International Journal of Research in Marketing.

Costley, C.L., \& Brucks, M. (1987). Product knowledge as an explanation for age-related differences in children's cognitive responses to advertising. ACR North American Advances.

Curtis, T., Abratt, R., Rhoades, D.L., \& Dion, P. (2011). Customer loyalty, repurchase and satisfaction: A meta-analytical review. Journal of Consumer Satisfaction, Dissatisfaction and Complaining Behavior, 24, 1.

Daugherty, T., Eastin, M.S., \& Bright, L. (2008). Exploring Consumer Motivations for Creating UserGenerated Content. Journal of Interactive Advertising, 8(2), 16-25.

Delgado-Ballester, E., \& Munuera-Alemán, J.L. (2005). Does brand trust matter to brand equity? Journal of Product \& Brand Management, 14(3), 187-96.

Dick, A.S., \& Basu, K. (1994). Customer loyalty: Toward an integrated conceptual framework. Journal of the Academy of Marketing Science, 22(2), 99-113.

Diller, H. (1996). Kundenbindung als Marketingziel. Marketing ZFP, 18(2), 81-94.

Erkan, I., \& Evans, C. (2016). The influence of eWOM in social media on consumers' purchase intentions: An extended approach to information adoption. Computers in Human Behavior, 61, $47-55$. 
Fournier, S., \& Yao, J.L. (1997). Reviving brand loyalty: A reconceptualization within the framework of consumer-brand relationships. International Journal of Research in Marketing, 14(5), 451-72.

Goh, K-Y., Heng, C-S., \& Lin, Z. (2013). Social Media Brand Community and Consumer Behavior: Quantifying the Relative Impact of User- and Marketer-Generated Content. Information Systems Research, 24(1), 88-107.

Gommans, M., Krishman, K.S., \& Scheffold, K.B. (2001). From brand loyalty to e-loyalty: A conceptual framework. Journal of Economic \& Social Research, 3(1).

Gurău, C. (2012). A life-stage analysis of consumer loyalty profile: comparing Generation X and Millennial consumers. Journal of Consumer Marketing, (D. Pitta, ed.), 29(2), 103-13.

Halliday, S.V. (2016). User-generated content about brands: Understanding its creators and consumers. Journal of Business Research, 69(1), 137-44.

Hegner, S. (2011). Die Relevanz des Vertrauens für das identitätsbasierte Management globaler Marken. Dissertation, Bremen: University of Bremen.

Hegner, S. (2012), Die Relevanz des Vertrauens für das identitätsbasierte Management globaler Marken. Wiesbaden: Gabler Verlag.

Hogreve, J., Iseke, A., Derfuss, K., \& Eller, T. (2017). The Service-Profit Chain: A Meta-Analytic Test of a Comprehensive Theoretical Framework. Journal of Marketing, 81(3), 41-61.

Hollebeek, L.D., \& Macky, K. (2019). Digital Content Marketing's Role in Fostering Consumer Engagement, Trust, and Value: Framework, Fundamental Propositions, and Implications. Journal of Interactive Marketing, 45, 27-41.

Hutcheson, G.D., \& Sofroniou, N. (1999). The multivariate social scientist: Introductory statistics using generalized linear models. Sage.

Jaritz, S. (2008). Kundenbindung und Involvement. Wiesbaden: Gabler.

Kim, A.J., \& Johnson, K.K.P. (2016). Power of consumers using social media: Examining the influences of brand-related user-generated content on Facebook. Computers in Human Behavior, 58, $98-$ 108.

Kim, Y., \& Peterson, R.A. (2017). A Meta-analysis of Online Trust Relationships in E-commerce. Journal of Interactive Marketing, 38, 44-54.

Kimmel, A.J. (2010). Connecting With Consumers: Marketing For New Marketplace Realities. Oxford: Oxford University Press.

Knox, S., \& Walker, D. (2003). Empirical developments in the measurement of involvement, brand loyalty and their relationship in grocery markets. Journal of Strategic Marketing, 11(4), 271-86.

Knox, S., Walker, D., \& Marshall, C. (2015). Are Grocery Brands Involving? In M.J. Sirgy, K.D. Bahn, \& T. Erem (Eds.), Proceedings of the 1993 World Marketing Congress (pp. 596-600). Cham: Springer International Publishing.

Komiak, S.X., \& Benbasat, I. (2004). Understanding Customer Trust in Agent-Mediated Electronic Commerce, Web-Mediated Electronic Commerce, and Traditional Commerce. Information Technology and Management, 5(1/2), 181-207.

Kuenzel, S., \& Halliday, S.V. (2010). The chain of effects from reputation and brand personality congruence to brand loyalty: The role of brand identification. Journal of Targeting, Measurement and Analysis for Marketing, 18(3-4), 167-76.

Laroche, M., Habibi, M.R., \& Richard, M-O. (2013). To be or not to be in social media: How brand loyalty is affected by social media? International Journal of Information Management, 33(1), 7682.

Laroche, M., Habibi, M.R., Richard, M-O., \& Sankaranarayanan, R. (2012). The effects of social media based brand communities on brand community markers, value creation practices, brand trust and brand loyalty0 Computers in Human Behavior, 28(5), 1755-67.

Lee, E.J., \& Shin, S.Y. (2014). When do consumers buy online product reviews? Effects of review quality, product type, and reviewer's photo. Computers in Human Behavior, 31(1), 356-366.

Lodes, M., \& Buff, C.L. (2009). Are Generation Y (Millennial) Consumers Brand Loyal and is Their Buying Behavior Affected in an Economic Recession? A Preliminary Study. Journal of the Academy of Business \& Economics, 9(3), 127. 
MacKinnon, K.A. (2012). User Generated Content vs. Advertising: Do Consumers Trust the Word of Others Over Advertisers? The Elon Journal of Undergraduate Research in Communications, 3(1), 14-22.

Malthouse, E.C., Calder, B.J., Kim, S.J., \& Vandenbosch, M. (2016). Evidence that user-generated content that produces engagement increases purchase behaviours. Journal of Marketing Management, 32(5-6), 427-444.

McKnight, H.D., Choudhury, V., \& Kacmar, C. (2002). The impact of initial consumer trust on intentions to transact with a web site: a trust building model. The Journal of Strategic Information Systems, 11(3), 297-323.

Mir, I.A., \& Rehman, K.U. (2013). Factors affecting consumer attitudes and intentions toward usergenerated product content on YouTube. Management \& Marketing, 8(4).

Nunally, J. (1978). Psychometric theory. New York: McGraw-Hill.

Oliver, R.L. (2014). Satisfaction: A Behavioral Perspective on the Consumer: A Behavioral Perspective on the Consumer. Routledge.

Ramanathan, U., Subramanian, N., \& Parrott, G. (2017). Role of social media in retail network operations and marketing to enhance customer satisfaction. International Journal of Operations \& Production Management, 37(1), 105-23.

Ramanathan, U., Subramanian, N., Yu, W., \& Vijaygopal, R. (2017). Impact of customer loyalty and service operations on customer behaviour and firm performance: empirical evidence from UK retail sector. Production Planning \& Control, 28(6-8), 478-488.

Roma, P., \& Aloini, D. (2019). How does brand-related user-generated content differ across social media? Evidence reloaded. Journal of Business Research, 96, 322-39.

Rowles, D. (2014). Digital Branding: A Complete Step-by-Step Guide to Strategy, Tactics and Measurement. Philadelphia: Kogan Page.

Schivinski, B., \& Dabrowski, D. (2015). The impact of brand communication on brand equity through Facebook. Journal of Research in Interactive Marketing, 9(1), 31-53.

Smith, R.E., \& Wright, W.F. (2004). Determinants of Customer Loyalty and Financial Performance. Journal of Management Accounting Research, 16(1), 183-205.

Social Media Examiner. (2018). Welcher Nutzen ergibt sich durch den Einsatz von Social Media Marketing für Ihr Unternehmen? Statista - Das Statistik-Portal.

Soh, H., Reid, L., \& Whitehill-King, K. (2009). Measuring trust in advertising: Development and validation of the Adtrust scale. Journal of Advertising, 38(2), 83-103.

Srinivasan, S.S., Anderson, R., \& Ponnavolu, K. (2002). Customer loyalty in e-commerce: an exploration of its antecedents and consequences. Journal of Retailing, 78(1), 41-50.

Statista. (2018). eCommerce Report 2019. Digital Market Outlook, Statista, 138.

Stöckl, R., Rohrmeier, P., \& Hess, T. (2008). Why Customers Produce User Generated Content. In Web 2.0: Neue Perspektiven für Marketing und Medien (pp. 271-87). Berlin, Heidelberg: Springer.

The CMO Survey. (2018). The CMO Survey: Highlights and Insights Report. cmosurvey.org, 95.

Too, L.H.Y., Souchon, A.L., \& Thirkell, P.C. (2001). Relationship Marketing and Customer Loyalty in a Retail Setting: A Dyadic Exploration. Journal of Marketing Management, 17(3-4), 287-319.

Urban, D., \& Mayerl, J. (2011). Regressionsanalyse: Theorie, Technik und Anwendung. Wiesbaden: VS Verlag für Sozialwissenschaften.

Utz, S., Kerkhof, P., \& Van den Bos, J. (2012). Consumers rule: How consumer reviews influence perceived trustworthiness of online stores. Electronic Commerce Research and Applications, 11, 49-58.

Vinhas Da Silva, R., \& Alwi, S.F.S. (2006). Cognitive, affective attributes and conative, behavioural responses in retail corporate branding. Journal of Product \& Brand Management, 15(5), 293305.

Vollmar, J., Becker, R., \& Hoffend, I. (Eds.). (2013). Macht des Vertrauens: Perspektiven und aktuelle Herausforderungen im unternehmerischen Kontext. Wiesbaden: Springer-Gabler.

Zaichkowsky, J.L. (1994). The Personal Involvement Inventory: Reduction, Revision, and Application to Advertising. Journal of Advertising, 23(4), 59-70. 